\title{
Salicylate Enables Cochlear Arachidonic-Acid-Sensitive NMDA Receptor Responses
}

\author{
Jérôme Ruel, ${ }^{1,3 *}$ Christian Chabbert, ${ }^{1,3 *}$ Régis Nouvian, ${ }^{1,3}$ Rim Bendris, ${ }^{1,3}$ Michel Eybalin, ${ }^{1,3}$ Claude Louis Leger, ${ }^{2}$ \\ Jérôme Bourien, ${ }^{1,3}$ Marcel Mersel, ${ }^{1,3}$ and Jean-Luc Puel ${ }^{1,3}$ \\ ${ }^{1}$ Inserm, Unité Mixte de Recherche 583, F-34091 Montpellier, France, and ²Laboratoire de Nutrition Humaine et Athérogénése, ${ }^{3}$ Université Montpellier 1, \\ F-34967 Montpellier, France
}

Currently, many millions of people treated for various ailments receive high doses of salicylate. Consequently, understanding the mechanisms by which salicylate induces tinnitus is an important issue for the research community. Behavioral testing in rats have shown that tinnitus induced by salicylate or mefenamate (both cyclooxygenase blockers) are mediated by cochlear NMDA receptors. Here we report that the synapses between the sensory inner hair cells and the dendrites of the cochlear spiral ganglion neurons express NMDA receptors. Patch-clamp recordings and two-photon calcium imaging demonstrated that salicylate and arachidonate (a substrate of cyclooxygenase) enabled the calcium flux and the neural excitatory effects of NMDA on cochlear spiral ganglion neurons. Salicylate also increased the arachidonate content of the whole cochlea in vivo. Single-unit recordings of auditory nerve fibers in adult guinea pig confirmed the neural excitatory effect of salicylate and the blockade of this effect by NMDA antagonist. These results suggest that salicylate inhibits cochlear cyclooxygenase, which increased levels of arachidonate. The increased levels of arachidonate then act on NMDA receptors to enable NMDA responses to glutamate that inner hair cells spontaneously release. This new pharmacological profile of salicylate provides a molecular mechanism for the generation of tinnitus at the periphery of the auditory system.

Key words: glutamate; salicylate; NMDA receptor; arachidonate; cochlea; tinnitus

\section{Introduction}

Therapeutic compounds containing salicylate have been used for thousands of years to treat various ailments. Today, salicylate is one of the most widely consumed anti-inflammatory drugs in the world. However, it has several side effects, such as gastrointestinal irritation, renal and hepatic dysfunction, allergic reactions, ringing in the ear (tinnitus), and a reversible 30-40 dB hearing loss. An explanation for the hearing loss is provided in the cochlea, in which salicylate competes with the contribution of cytoplasmic chloride to nonlinear capacitance of sensory outer hair cells (OHCs) (Kakehata and Santos-Sacchi, 1996; Zheng et al., 2000; Oliver et al., 2001; Zhang et al., 2001). However, the mechanisms underlying salicylate induced-tinnitus remain unclear.

Experiments in animals have shown that salicylate increases the spontaneous activity of single units of the auditory nerve (Evans et al., 1981; Evans and Borerwe, 1982; Stypulkowski, 1990) and modifies the average spectrum activity recorded from the round window, which is a gross measure of the spontaneous activity of the auditory nerve (Schreiner and Snyder, 1987; Martin et al., 1993; Cazals et al., 1998; McMahon and Patuzzi, 2002).

Received Dec. 2, 2007; revised May 20, 2008; accepted May 20, 2008.

This work was supported by Auris Medical and Tinnitus Research Initiative. We gratefully acknowledge Prof. R.P. Bobbin for helpful criticisms, Dr. Ruth Lloyd for careful editing of the manuscript, Nicole Renard for technical help, and Dr. Hassan Boukhaddaoui for help with the Imaris software.

* J.R. and C.C. contributed equally to this work.

Correspondence should be addressed to Prof. Jean-Luc Puel, Inserm, Unité Mixte de Recherche 583, Institut des Neurosciences, 80 Avenue Augustin Fliche, F-34091 Montpellier cedex, France. E-mail: jean-luc.pue!@inserm.fr. DOI:10.1523/JNEUROSCI.5335-07.2008

Copyright $\odot 2008$ Society for Neuroscience $\quad$ 0270-6474/08/287313-11\$15.00/0
These effects suggest that tinnitus induced by salicylate is associated with dysfunction of the auditory nerve. Based on behavioral testing, Guitton et al. (2003) have demonstrated that application of NMDA antagonists directly into cochlear fluids blocks the tinnitus induced by salicylate. Because salicylate is known to block cyclooxygenase activity, the same authors tested the ability of mefenamate, another cyclooxygenase blocker, to produce tinnitus in rats. They found that mefenamate does indeed induce tinnitus that can be blocked by NMDA antagonists. Together, these results provide evidence that the cochlea is a generation site of salicylate-induced tinnitus and that salicylate may act through the cyclooxygenase pathway to activate or enable cochlear NMDA receptors. Therefore, we tested the hypothesis that salicylate induces tinnitus by increasing the afferent neuronal activity by way of NMDA receptors located in the cochlea and that the cyclooxygenase pathway is involved.

\section{Materials and Methods}

Neonatal and adult Wistar rats and adult pigmented guinea pigs were used. The care and use of animals followed the animal welfare guidelines of Inserm and were under the approval of the French Ministère de l'Agriculture et de la Pêche. All efforts were made to minimize the number of animals used and their suffering.

\section{SDS-PAGE and Western blot analysis}

Adult rat cochleae $(n=4)$ were rapidly dissected in PBS containing anti-protease (pepstatin, leupeptin, and antipain, $10 \mu \mathrm{g} / \mathrm{ml}$ each; Roche Diagnostics) and frozen. Protein extracts were prepared by homogenizing the thawed cochleae in $350 \mu \mathrm{l}$ of $50 \mathrm{~mm}$ Tris- $\mathrm{HCl}$, $\mathrm{pH}$ 7.5, containing $150 \mathrm{~mm} \mathrm{NaCl}$ and the antiproteases. The homogenate was then centri- 
fuged $2 \mathrm{~min}$ at $1000 \times g$ to pellet large cellular and bone debris. The protein content of the homogenates was assayed using the BCA Protein Assay Reagent kit (Pierce). The samples were diluted to $1 \mu \mathrm{g} / \mu \mathrm{l}$ in $50 \mathrm{~mm}$ Tris-HCl, pH 6.8, 10\% glycerol, $2 \%$ SDS, $5 \% \beta$-mercaptoethanol, $0.002 \%$, and bromophenol blue, heated for $15 \mathrm{~min}$ at $55^{\circ} \mathrm{C}$, and stored at $-80^{\circ} \mathrm{C}$.

Proteins (15 $\mu \mathrm{g} /$ lane) were electrophoresed in $7.5-10 \%$ acrylamide gels, electroblotted onto polyvinylidene difluoride membranes, and processed for NMDA receptor subunit detection using an alkaline phosphatase kit according to the instructions of the manufacturer (5-bromo-4chlor-indolyl-phosphate/nitroblue-tetrazolium-chloride purple liquid substrate system for membranes; Sigma). Briefly, the membranes were blocked with $5 \%$ skimmed milk in Tris-buffered saline containing $0.1 \%$ Tween 20 and incubated overnight at $4^{\circ} \mathrm{C}$ with the primary antibodies diluted in this buffer before proceeding to the alkaline phosphatase detection.

The monoclonal NR1 antibody (clone 54-1; BD Biosciences) recognizes the extracellular loop between the transmembrane region 3 and 4 . It shows no cross-reactivity with other NMDA receptor subunits. It was used diluted to 1:1000. The antibodies against the NR2 subunits were all raised in rabbits. The anti-NR2A antibody (Millipore) was raised against the last 200 amino acids of the $\mathrm{C}$ terminus of mouse NR2A. It was used diluted to 1:1000. The anti-NR2B (Millipore) was raised against amino acids 1437-1456 of the mature rat NR2B. It was used diluted to 1:500. The NR2C antibody (Novus Biologicals) was raised against amino acids $25-130$ of rat NR2C. It recognizes at $140 \mathrm{kDa}$ NR2C and at $\sim 180 \mathrm{kDa}$ NR2A and NR2B. It was used diluted to 1:100. The anti-NR2D antibody (Santa Cruz Biotechnology) was raised against amino acids 268-386 of human NR2D. It was used diluted to 1:500.

\section{Immunocytochemistry}

Light microscopy immunocytochemistry. Rat cochleae (350 g; $n=5$ ) were immersion fixed for $1 \mathrm{~h}$ in $4 \%$ paraformaldehyde diluted in PBS $\left(4^{\circ} \mathrm{C}\right)$. They were then dissected in PBS, and the otic capsule and the stria vascularis were removed. Cryostat sections $(10 \mu \mathrm{m})$ were cut and stored at $-20^{\circ} \mathrm{C}$ until use.

Thawed sections were rinsed three times for $8 \mathrm{~min}$ in PBS, preincubated $1 \mathrm{~h}$ in $30 \%$ normal goat serum and $0.3 \%$ Triton $\mathrm{X}-100$, and incubated overnight at $4^{\circ} \mathrm{C}$ with the mouse anti-NR1 antibody and a rabbit anti-parvalbumin antibody (Swant), to delineate the outlines of inner hair cells (IHCs) (Eybalin and Ripoll, 1990). The mouse monoclonal was used diluted to 1:250 and the rabbit polyclonal to 1:750 in PBS containing $1 \%$ normal goat serum. Sections were then rinsed in PBS (three times for $8 \mathrm{~min}$ ) and incubated $2 \mathrm{~h}$ in goat anti-rabbit IgGs conjugated to Alexa 488 and goat anti-mouse IgGs conjugated to Alexa 568 (Invitrogen) diluted to 1:2000 in PBS. The sections were rinsed in PBS (three times for $8 \mathrm{~min}$ ), mounted in Mowiol, and examined with a Leica DMRB epifluorescence microscope and the Bio-Rad MRC1024 laser-scanning confocal microscope of the Montpellier RIO Imaging facility, located at the Institut Universitaire de Recherche Clinique. The fluorescence emissions were collected sequentially using the 488 and $568 \mathrm{~nm}$ lines for Alexa 488 and Alexa 568, respectively, to minimize bleed-through between the emitted fluorescences. Some IHCs were three-dimensionally reconstructed from the confocal images using a surface rendering technique with IMARIS (Bitplane).

Negative controls were performed by omitting the primary antibodies in the first incubation step or by substituting them with IgGs. No fluorescence could be observed under these conditions. For double immunofluorescence, we further assayed the species specificity of the secondary antibodies. The sections were incubated with only one primary antibody and then with both anti-rabbit and anti-mouse secondary antibodies. In all the cases, only the specific fluorescence was observed.

Electron microscopy immunocytochemistry. Rats (250-300 g; $n=12)$ and guinea pigs ( $350 \mathrm{~g} ; n=14$ ) were intracardially perfused with $4 \%$ paraformaldehyde and $0.2 \%$ glutaraldehyde in $0.1 \mathrm{M}$ phosphate buffer, pH 7.4, under deep sodium pentobarbital anesthesia. After an overnight postfixation in the $4 \%$ paraformaldehyde at $4^{\circ} \mathrm{C}$, the cochleae were rinsed several times in the phosphate buffer and dissected from their bony capsule.
They were then preincubated for $30 \mathrm{~min}$ in $30 \%$ normal goat serum in PBS and incubated for $60 \mathrm{~h}$ at $4^{\circ} \mathrm{C}$ with the anti-NR antibody diluted to 1:100-1:250 in PBS and 1\% normal goat serum. After two rinses for 10 min in the PBS, the cochleae were incubated with goat anti-rabbit or mouse IgGs Fab fragments conjugated to HRP diluted to 1:100 (AbCys) for $1 \mathrm{~h}$. After additional rinses in a Tris-buffered saline, the cytochemical reaction of HRP was revealed using diaminobenzidine- $\mathrm{H}_{2} \mathrm{O}_{2}$ as a chromogen. After additional rinses, the samples were osmicated, dehydrated in graded ethanol and propylene oxide, and embedded in Epon. Pale gold thin sections were taken using a diamond knife and observed uncontrasted at $55 \mathrm{kV}$ on the Hitachi H7100 electron microscope of the CRIC Electron Microcopy Facility of Montpellier1 University. Images were taken using the AMT XR611 camera of the microscope. Control experiments were performed by incubating the cochleae in the absence of the primary antibodies.

In addition to the mouse monoclonal against NR1 (clone 54-1), we used two rabbit polyclonal antibodies, one against the C-terminal part of NR1 (Millipore Bioscience Research Reagents) and the second recognizing the C-terminal part of NR2A and NR2B (anti-NR2A/B; Millipore Bioscience Research Reagents).

\section{Drug preparation}

Glutamate (Glu) (Sigma), AMPA (Tocris), NMDA (Tocris), and sodium salicylate (NaSal) (VWR Prolabo) were freshly prepared before each experiment and used at concentrations of 1 and $5 \mathrm{~mm}$. NMDA antagonist dizocilpine $[(+)-5$-methyl-10,11-dihydro-5H-dibenzo $[\mathrm{a}, \mathrm{d}]$ cyclohepten-5,10-imine maleate (MK-801)] (Tocris) was used at a concentration of $50 \mu \mathrm{M}$. MK-801 was dissolved in DMSO to make stock solutions and stored at $-4^{\circ} \mathrm{C}$ until used. Before each experiment, drugs were diluted in artificial perilymph to reach the tested concentration. The amount of DMSO was adjusted to maintain a $0.1 \%$ concentration for each MK-801 dilution. (-)1-(4-aminophenyl)-4-methyl-7,8-methylenedioxy-4,5-dihydro-3-methylcarbamoyl-2,3-benzodiazepine (GYKI 53784) (gift from Lilly Research Laboratories) was dissolved in methanol to make $40 \mathrm{~mm}$ stock solutions and stored at $-4^{\circ} \mathrm{C}$ until use (Ruel et al., 2000). Before each experiment, it was diluted in artificial perilymph to reach a $50 \mu \mathrm{M}$ concentration. The amount of methanol was adjusted to maintain a $0.4 \%$ concentration for each drug dilution. Sodium arachidonate (Sigma) was freshly diluted in artificial perilymph at $10 \mu \mathrm{M}$ concentration before each experiment. Additional experiments used an artificial perilymph containing $0 \mathrm{Mg}^{2+}$ with $10 \mu \mathrm{M}$ glycine (VWR Prolabo).

\section{Functional assessment in vitro}

Retrograde labeling of the cochlear nerve. Retrograde labeling of the cochlear nerve has been described previously (Boyer et al., 2004). Briefly, the mandible of the postnatal day 1 (P1) to P5 rats was removed, and the head was cut in the sagittal axis after decapitation. Half-heads were stuck into the Petri dish with Super Glue. The Petri dish was carefully filled with the oxygenated dissection solution at room temperature $\left(23^{\circ} \mathrm{C}\right)$. The endocranial cavity around the emergence of the sectioned auditory nerve was dried, and small pieces of foam were stuck to form a tight compartment. Because the dextran-conjugated dyes are only taken up into recently cut axons, the compartment was filled within $1 \mathrm{~min}$ of the cochlear nerve being cut. The dyes were left in contact with the auditory nerve over a period of $30 \mathrm{~min}$, allowing the axons time to reseal. The half-head preparation was fully immerged in the oxygenated dissecting solution and left in the dark for $6 \mathrm{~h}$.

Cochlear slice preparation. Cochlear slices (P1-P5) were prepared according to Jagger et al. (2000). The half-head was dissected in chilled slicing solution $\left(4^{\circ} \mathrm{C}\right)$ to remove the temporal bones. Because the slicing procedure damages the cochlea, the morphology of the sensory epithelium was protected by the introduction of a gel within the scalae. This was achieved by infusing a solution of artificial perilymph containing $35 \%$ pluronic gel at $4^{\circ} \mathrm{C}$ via a glass micropipette inserted in the round window niche, with the infused solution flowing out of the cochlea through the opened oval window. The cochlea was then carefully oriented to obtain planar slices in the modiolar plane that radially transected the three scalae. The whole cochlea slicing was done in a slicing solution at room 
temperature (which solidifies the pluronic gel), and several slices of $250-$ $300 \mu \mathrm{m}$ thickness were obtained. Cochlear slices were then transferred to the chilled oxygenated slicing solution to dissociate the pluronic gel from the cochlear tissue and laid to recover for $15 \mathrm{~min}$. The slice preparations were then mounted in a recording chamber perfused at $1 \mathrm{ml} / \mathrm{min}$ with warmed $\left(23^{\circ} \mathrm{C}\right)$ and oxygenated $\left(95 \% \mathrm{O}_{2}, 5 \% \mathrm{CO}_{2}\right)$ recording solution.

Calcium imaging technique. Calcium imaging was accomplished with a two-photon laser-scanning microscope system that consisted of a femtosecond-pulsed titanium:sapphire laser (Tsunami; Spectra-Physics) pumped with a $5.5 \mathrm{~W}$ diode-pumped solid-state laser (Millenia Vs-P; Spectra-Physics), a retrofitted Bio-Rad Radiance 2000 scan box, and an upright microscope (BX50WI; Olympus Optical) equipped with a $60 \times$ objective LUMPlanFL ( $60 \times$ water immersion/0.9 infrared). The beam intensity was controlled by a continuous intensity control module (Pockels cell, model 350-50; ConOptics). Cochlear spiral ganglion neurons loaded with Calcium Green-1 (Invitrogen) were imaged at $810 \mathrm{~nm}$ excitation. Emission light was collected at $530 \mathrm{~nm}$ (HQ575/150 bandpass filter; Chroma Technology) by photomultiplier tubes. For time series experiments, images were acquired at 0.5 or $1 \mathrm{~Hz}$ using the line scan or the time laps mode of Bio-Rad software (Laser sharp 2000), respectively. Normalized fluorescent changes were estimated as $\Delta F / F=\left(F_{n}-F_{0}\right) / F_{0}$, where $F_{n}$ is the background corrected average intensity within the measurement box in frame $n$, and $F_{0}$ is the background corrected average intensity averaged over five frames at the beginning of the sequence (i.e., before Glu applications).

Patch-clamp recordings. The somata of cochlear spiral ganglion neurons were voltage or current clamped using the whole-cell configuration of the patch-clamp technique with an Axopatch 200B patch-clamp amplifier (MDS Analytical Technologies; Molecular Devices). Patch pipettes were formed from borosilicate capillary tubing (microhematocrite tubing; Modulhom) using a Narishige PP-830 puller. The electrode tip had a resistance ranging from 2 to $3 \mathrm{M} \Omega$ when filled with the internal solution containing the following (in mM): $145 \mathrm{KCl}, 0.5 \mathrm{MgCl}_{2}, 5 \mathrm{HEPES}$, 11 EGTA, $0.1 \mathrm{CaCl}_{2}, 2 \mathrm{Na}_{2} \mathrm{ATP}$, and $0.1 \mathrm{Na}_{2} \mathrm{GTP}$. After seal formation onto the membrane of cochlear spiral ganglion neurons and membrane disruption, cell capacitance and series resistance were estimated from the decay of the capacitance transient induced by a $\pm 10 \mathrm{mV}$ pulse from a holding potential of $-100 \mathrm{mV}$. Series resistances were compensated up to $80 \%$ after cancellation of the capacitive transients. Membrane currents were sampled at $5 \mathrm{kHz}$ (pClamp8; Molecular Devices) and filtered at half the sampling rate (eight-pole low-pass Bessel filter), digitized with a 16bit analog-to-digital converter (DigiData 1322A Interface; Molecular Devices).

Iontophoretic application of the drugs. To optimize two-photon $\left[\mathrm{Ca}^{2+}\right]_{\mathrm{i}}$ measurements in single postsynaptic afferent boutons, drugs were applied iontophoretically. Glass micropipettes containing solutions of $10 \mathrm{~mm}$ Glu were used for iontophoretic application at the postsynaptic pole of the IHCs. The ejecting currents were ranged between 100 and 500 $\mathrm{nA}$. To prevent leakage of the drugs from the micropipette tips, constant positive retaining currents $(2-5 \mathrm{nA})$ were passed through the pipettes with Glu. Applications of $\mathrm{Cl}^{-}$or $\mathrm{Na}^{+}$alone were used as control.

\section{Functional assessment in vivo}

Adult pigmented guinea pigs (250 to $300 \mathrm{~g}$; Charles River), free of middle-ear infection, were anesthetized with urethane $(1.4 \mathrm{~g} / \mathrm{kg}$, i.p.; Sanofi) and ventilated during the experiment. Supplemental doses $(0.35$ $\mathrm{g} / \mathrm{kg}$, i.p.) were administered every $2 \mathrm{~h}$ or more often if the animal withdrew its paw in response to deep pressure applied to the paw. A tracheotomy was performed, the electrocardiogram was monitored, and the central temperature was regulated at $38 \pm 1^{\circ} \mathrm{C}$ by a thermal regulated heating blanket. The pinna and external auditory meatus were resected to ensure good close-field acoustic stimulation.

Perilymphatic perfusion technique. The method used to monitor the effect of multiple perilymphatic perfusions on sound-evoked potentials has been extensively described previously (Puel, 1995). The cochlea was exposed ventrally, and two holes $(0.2 \mathrm{~mm}$ in diameter) were gently drilled in the scala vestibuli and scala tympani of the basal turn of the cochlea. Intracochlear perfusions entered through the hole in the scala tympani at $2.5 \mu \mathrm{l} / \mathrm{min}$ and flowed out of the cochlea through the hole in the scala vestibuli. All perfusions lasted $10 \mathrm{~min}$. The artificial perilymph solution had the following composition (in $\mathrm{mm}$ ): $137 \mathrm{NaCl}, 5 \mathrm{KCl}, 2$ $\mathrm{CaCl}_{2}, 1 \mathrm{MgCl}_{2}, 1 \mathrm{NaHCO}_{3}, 11$ glucose, and 10 HEPES. The $\mathrm{pH}$ was 7.4 and osmolarity was maintained at $300 \mathrm{mOsm} / \mathrm{kg} \mathrm{H}_{2} \mathrm{O}$.

Compound action potential of the auditory nerve. Compound action potential of the auditory nerve (CAP) was elicited using tone bursts with a $1 \mathrm{~ms}$ rise/fall time and a $9 \mathrm{~ms}$ total duration generated by an arbitrary function generator (type 9100R; LeCroy Corporation). The signals were passed through a programmable attenuator and presented to the ear in free field via a JBL 075 earphone. Ten frequencies were tested $(2,4,6,8$, $10,12,16,20,26$, and $32 \mathrm{kHz}$ ), with increasing levels of $5 \mathrm{~dB}$ from 0 to 100 $\mathrm{dB}$ sound pressure level (SPL) (reference $2 \cdot 10^{-5} \mathrm{~Pa}$ ). The rate of presentation was 10 bursts per second. Cochlear responses were amplified (gain of 2000) by a differential amplifier (Grass P511K; Astro-Med), and the signals were filtered (bandpass, $100 \mathrm{~Hz}$ to $3 \mathrm{kHz}$ ) and averaged (256 tests) on a Pentium personal computer (Dell Computer Company). The sampling rate of the analog-to-digital converter was $50 \mathrm{kHz}$, with a dynamic range of 12 bits and 1024 samples per record. CAPs were measured peak-to-peak between the first negative $\left(\mathrm{N}_{1}\right)$ and the following positive value $\left(\mathrm{P}_{1}\right)$. The thresholds were defined as the level of decibels SPL needed to elicit a measurable response ranged from 2 to $5 \mu \mathrm{V}$.

Distortion product otoacoustic emissions. Distortion product otoacoustic emissions (DPOAEs) were recorded in the external auditory canal using an Etymotic research probe consisting of two emitters and one microphone. The sound was generated and processed using the Cubdis system (Mimosa Acoustics). The probe was self-calibrated before each recording. An $f_{2}$ frequency was swept from 0.5 to $20 \mathrm{kHz}$ by quarter octave steps, with the $f_{2} / f_{1}$ ratio being maintained at a constant 1.2. The primary frequencies for $f_{2}$ and $f_{1}$ were 60 and $55 \mathrm{~dB} \mathrm{SPL}$ ), respectively. For each frequency, the cubic distortion product $2 f_{1}-f_{2}$ was measured and expressed as a function of $f_{2}$.

Single-unit recording from the auditory nerve. The method to record single units of the auditory nerve has been described previously (Ruel et al., 1999). Briefly, the cochlear nerve was exposed using a posterior fossa approach. Extracellular action potentials from single auditory nerve fibers were recorded with glass microelectrodes (tip diameter, $0.1-0.5$ $\mu \mathrm{m}$ ) filled with $4 \mathrm{M} \mathrm{NaCl}$, having an in vivo resistance between 20 and 60 $\mathrm{M} \Omega$. The unit activity was tracked by advancing the microelectrode through the cochlear nerve with a motorized micromanipulator during exposure to $80 \mathrm{~dB}$ SPL white noise generated by a Brüel and Kjær (type 1405; bandwidth, $100 \mathrm{kHz}$ ). A silver-silver chlorided reference wire was placed in the animal's neck musculature and coupled to the recording microelectrode, connected to a preamplifier. The resulting signal was amplified by a direct current powered amplifier (Radio Spares VIP 20), and the analog signals were converted digitally (sampling frequency, 48 $\mathrm{kHz}$ ) using a 24-bit converter (model 4474; National Instruments). The action potentials were detected with custom-made software (Bourien et al., 2007). The detector was composed of a bandpass finite-impulseresponse filter with complex coefficients in the first stage to increase the signal-to-noise ratio and a decision rule in the second stage. The parameters of the filter were $f_{0}=500 \mathrm{~Hz}$ and $k=2$, and the threshold-value of the decision rule was adapted visually by the experimenter.

Quantification of interspike interval distribution were computed as the mean spike rate and coefficient of variation. The spike rate was computed each second for a window width of $1 \mathrm{~s}$ without overlapping. The coefficient of variation, defined as the ratio of the SD and the mean of the interspike intervals, was computed every $100 \mathrm{~s}$ for a window size of $100 \mathrm{~s}$ without overlapping. This window size provided a correct estimation of the coefficient of variation even for low instantaneous spike rate fibers. The significance of variations in the spike rate and the coefficient of variation values was evaluated between temporal windows of $60 \mathrm{~s}$ selected in single-unit activity during control artificial perilymph, NaSal perfusion with or without MK-801. Data acquisition and data processing were performed on a personal computer (Dell Precision PWS380).

Cochlear lipid extraction and arachidonate content determination All organic solvents were HPLC grade. Thawed cochleae were dipped in $350 \mu$ of perilymph containing 1:5000 (v/v) trifluoroacetylarachidonate (Sigma), an anti-phospholipase A2 inhibitor; the stock solution was 
$0.025 \%(\mathrm{w} / \mathrm{v})$ in DMSO. Then $50 \mu \mathrm{l}$ of MilliQ water were added, and total lipids were extracted according to the study of Folch et al. (1957). Briefly, after adding chloroform/methanol [2:1, v/v (Folch et al., 1957)], cochleae were homogenized as described above (four strokes, $15 \mathrm{~s}$ each, at $2000 \mathrm{rpm}$ ). Subsequent to extraction the organic phase was filtered through 1SP Filters (Whatman), washed first with $0.74 \% \mathrm{KCl}$ in MilliQ water, and then again with the Folch upper phase (chloroform/metha$\left.\mathrm{nol} / \mathrm{H}_{2} \mathrm{O}, 3: 48: 47, \mathrm{v} / \mathrm{v} / \mathrm{v}\right)$. The organic phase was evaporated to dryness and kept in Folch in sealed vials at $-20^{\circ} \mathrm{C}$; for long conservation times, $0.05 \%(w / v)$ 2,6-di-tert-butyl-4-methylphenol (BHT) (Sigma) was added. When needed, samples were evaporated under a nitrogen stream, dissolved in Folch $(10-50 \mu \mathrm{l})$, and spotted on aluminum sheets for silica thin-layer chromatography (TLC) (Merck). TLC sheets were washed (ascendant chromatography) with chloroform/methanol $(1: 1, \mathrm{v} / \mathrm{v})$ and activated at $80^{\circ} \mathrm{C}$ overnight. The eluant system was petroleum ether (boiling point, $\left.60-80^{\circ} \mathrm{C}\right) /$ diethylether/acetic acid $(80: 20: 1, \mathrm{v} / \mathrm{v} / \mathrm{v})$. All standards (triglycerides, fatty acids, diglycerides, cholesterol, and sodium arachidonate) were of purest quality and were purchased from Sigma; arachidonate, $R_{f}$ of which is 0.14 , was not contaminated by other neutral lipids.

After chromatography, lipids were detected by iodine vapors, and spots corresponding to arachidonate were delimited. Iodine was evaporated at room temperature, and area corresponding to arachidonate was cut and extracted overnight in chloroform/methanol $(1: 1, \mathrm{v} / \mathrm{v})$. After evaporation to dryness under a nitrogen stream, the lipid residue was submitted to gas liquid chromatography (GLC). Briefly, samples were first transesterified for $6 \mathrm{~h}$ at $65^{\circ} \mathrm{C}$ in $200 \mu \mathrm{l}$ of methanol/36\% $\mathrm{HCl} /$ dimethoxypropane mixture (16:1.6:0.64, v/v/v) containing 0.05\% BHT. The fatty acid methyl esters were extracted with hexane (600 and $300 \mu \mathrm{l}$ successively) and then again evaporated under a nitrogen stream to dryness. The residue was dissolved in isooctane $(50 \mu \mathrm{l})$ and submitted to GLC using Fisons GC 8000 equipped with a capillary column (JW Scientific, Interchim) whose characteristics were as follows: $60 \mathrm{~m} \times 0.25 \mathrm{~mm}$ internal diameter, coated with a $0.15 \mu \mathrm{m}$ DBWax film thickness. Analyses were performed at $220^{\circ} \mathrm{C}$ after injection (in the split mode) of $2 \mu \mathrm{l}$ at $230^{\circ} \mathrm{C}$ and flame ionization detection at $240^{\circ} \mathrm{C}$. Hydrogen was used as the carrier gas at a flow rate of $1.5 \mathrm{ml} / \mathrm{min}(160 \mathrm{kPa})$. Arachidonic acid was quantified by means of hetadecanoic acid (Sigma), as internal standard, introduced before the transesterification step. Calculations were performed using the Kontron Instruments chromatography data system KromaSystem 2000. Organic phosphorus was measured as follows: area of TLC corresponding to polar lipids (phospholipids, $R_{f}=0$ ) were extracted as described for arachidonate, and total organic phosphorus was determined according to Rouser et al. (1967). Arachidonate quantities (nanomoles) were standardized with regard to organic phosphorus content (nanomoles). Results are also expressed in concentrations (nanomoles per cochlea volume).

\section{Statistical analysis}

Data measurement and analysis were performed with Clampfit (Molecular Devices) for in vitro experiments. All the results are expressed as means \pm SE $(n)$, where $n$ refers to number of neurons. All statistics were done using SigmaPlot 2000 for Windows (version 6.1). All comparisons between means were performed using Student's paired samples two-tail $t$ tests and ANOVAs (Student-Newman-Keuls test) when appropriate.

\section{Results}

\section{Expression and localization of NMDA receptors}

Western blots of NMDA receptor subunits performed in rat cochleae showed bands at $120 \mathrm{kDa}$ for NR1, $180 \mathrm{kDa}$ for NR2B, and $150 \mathrm{kDa}$ for NR2D. A faint band could be seen for NR2C at 140 $\mathrm{kDa}$, whereas NR2A was not detected (Fig. 1).

At the epifluorescence (Fig. 2A) or confocal microscope (Fig. 2B) (supplemental Movie 1, available at www.jneurosci.org as supplemental material), the IHC basal poles were surrounded by NR1-immunoreactive dots. Three-dimensional reconstructions (Fig. 2C,D) (supplemental Movie 2, available at www. jneurosci.org as supplemental material) clearly showed that these

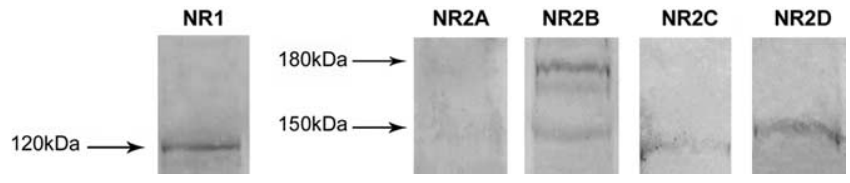

Figure 1. Immunoblot analysis of NMDA receptor subunits in rat cochlear homogenates. The NR1 immunoreactivity migrated as a single band at $\sim 120 \mathrm{kDa}$ and that of NR2B, NR2C, and NR2D at $\sim 180, \sim 140$, and $\sim 150 \mathrm{kDa}$, respectively. Additional bands at lower molecular weights could also be seen in the NR2B lane. No NR2A immunoreactivity could be detected.
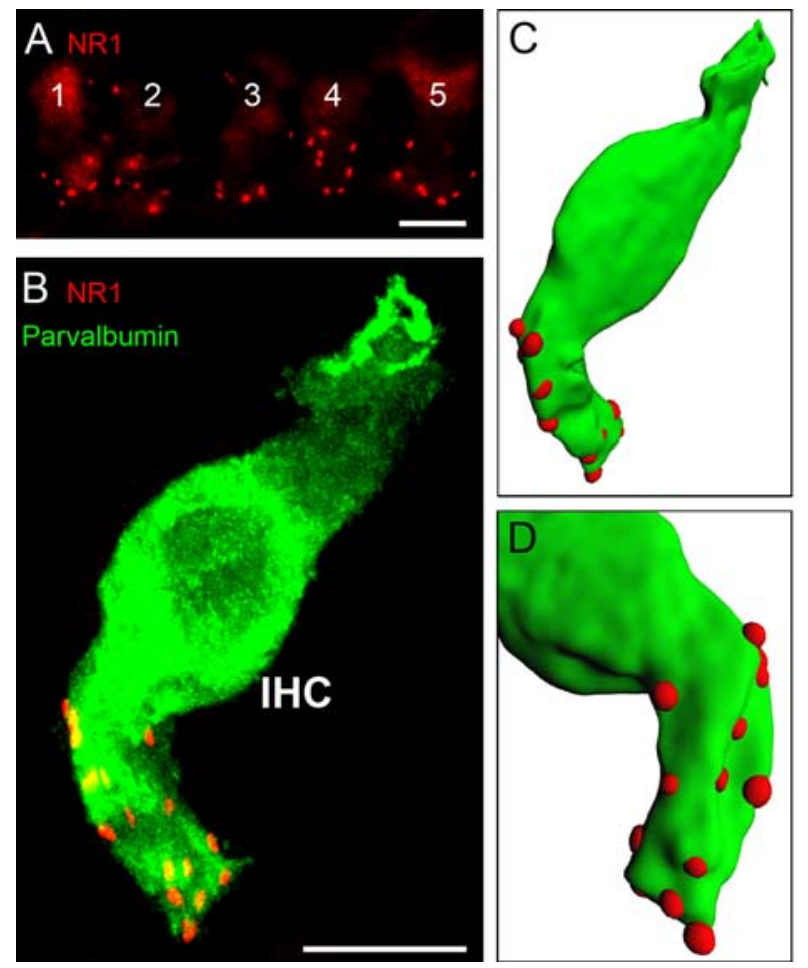

Figure 2. Immunofluorescence localization of NMDA receptors in the rat cochlea. $\boldsymbol{A}$, Cryostat section through several IHCs of the apical turn, numbered 1-5, observed using an epifluorescence microscope. NR1-immunoreactive dots in the focus plane are found at the basal poles of the cells. Scale bar, $10 \mu \mathrm{m}$. $\boldsymbol{B}$, High-magnification confocal microscopy of an IHC from a cryostat section through the medial turn. The image shown is a projection of $710.25-\mu \mathrm{m}$-thick optical sections so that it includes the whole cell with its postsynaptic contacts (for the whole stack, see supplemental Movie 1, available at www.jneurosci.org as supplemental material). The IHC was immunolabeled with an anti-parvalbumin antibody (green). NR1-immunoreactive dots (red) are associated with the IHC basal pole. Scale bar, $10 \mu \mathrm{m}$. C, D, Three-dimensional reconstructions of the IHC using a surface rendering technique clearly show that the NR1-immunoreactive dots are apposed to the hair cell membrane (for an animated reconstruction, see supplemental Movie 2, available at www.jneurosci.org as supplemental material).

dots were in fact apposed to the hair cells. A count on 33 IHCs from the basal and medial turns of five cochleae gave 459 NR1positive dots with a mean of $13.91 \pm 0.95 \mathrm{NR} 1$-positive dots per IHC.

At the electron microscopic level, the NR1 (Fig. $3 A-D$ ) and NR2A/B (Fig. 3E, F) immunoreactivities appeared as a dense and dark $\mathrm{DAB}$ deposit thickening the postsynaptic membrane facing the presynaptic ribbons. This DAB deposit was still present, although the ribbons had disappeared on the presynaptic side (Fig. $3 A$ ). The NR1 immunoreactivity was found on all 47 synapses from 27 IHCs, of 9 guinea pig cochleae we observed. The same observation could be made concerning the NR2A/B immunoreactivity on the 11 synapses observed from seven IHCs of five guinea pig cochleae. A careful high-magnification examination of 

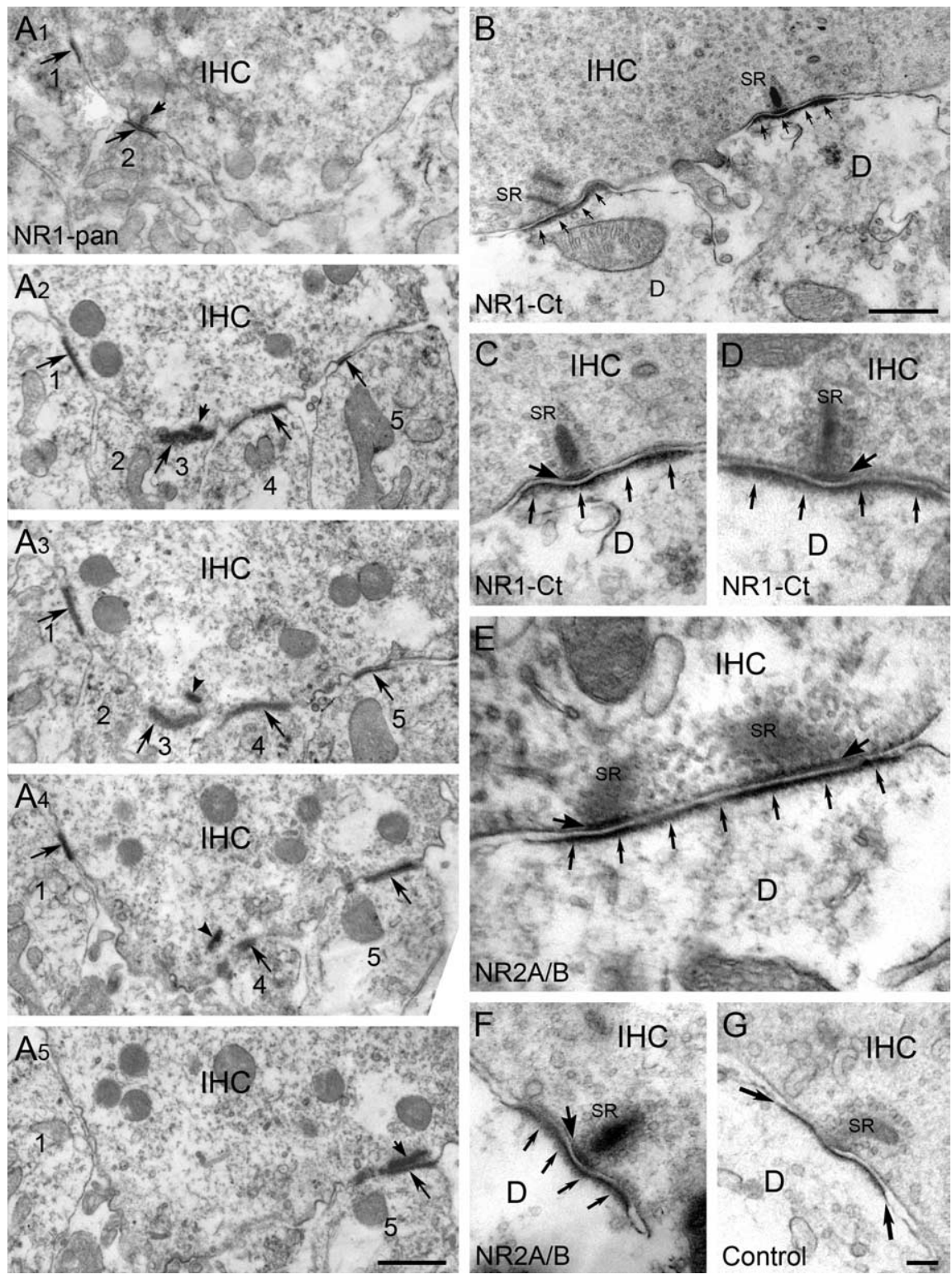

Figure 3. Ultrastructural immunocytochemistry of NMDA receptor subunits in the guinea pig cochlea using antibodies against NR1-pan (A1-A5), C-terminal NR1 $(\boldsymbol{B}-\boldsymbol{D})$ and C-terminal NR2A/B $(\boldsymbol{E}, \boldsymbol{F})$, and negative control (G). $\boldsymbol{A} \mathbf{1}-\boldsymbol{A}$, Semiserial sections through an IHC base showing five NR1-immunoreactive dendritic terminals of primary auditory neurons. The postsynaptic densities (arrows) are darkened and thickened by the DAB end product locating the NR1 immunoreactivity. The short arrows point to presynaptic ribbons and the arrowhead to recycling ribbons at distance from the synaptic membrane. Scale bar, $1 \mu \mathrm{m}$. $\boldsymbol{B}$, Two synapses at the IHC base showing dark and thickened NR1-immunoreactive postsynaptic densities (arrows) facing, on the right, a single synaptic ribbon (SR) and, on the left, a synaptic ribbon and a recycling ribbon. D, Dendrite of auditory neurons. Scale bar, $500 \mathrm{~nm}$. $\boldsymbol{C}-\boldsymbol{F}$, High magnification of four synapses showing NR1 $(\boldsymbol{C}, \boldsymbol{D})$ and NR2A/B $(\boldsymbol{E}, \boldsymbol{F})$ immunoreactivities in the postsynaptic density (arrows) and beneath the presynaptic ribbon (large arrow). Note that $\boldsymbol{C}$ is the synapse on the right in $\boldsymbol{B}$ and that the synapse in $\boldsymbol{E}$ possesses two synaptic ribbons facing the NR2A/B-immunoreactive postsynaptic density. $\boldsymbol{G}$, The postsynaptic density in this negative control synapse, although somewhat darker and thicker than the dendritic membrane outside the active zone, appears less dark and much thinner than in the NR-immunopositive postsynaptic membrane. Scale bar: (in $\mathbf{G}$ ) $\mathbf{C}-\boldsymbol{F}, 100 \mathrm{~nm}$.

these synapses also enabled us to observe a thin DAB deposit on the presynaptic membrane beneath the synaptic ribbon (Fig. $3 C-$ $F$ ). Finally, control cochleae incubated without primary antibody displayed no immunoreactivity over the postsynaptic density or beneath the synaptic ribbon on the presynaptic side (Fig. 3G).

\section{Salicylate increases Glu responses of cochlear spiral ganglion neurons}

To investigate the molecular mechanisms of salicylate on cochlear NMDA receptors, we examined its effects in slices of neo- natal rat cochleae (Fig. $4 A, B$ ). Application of $5 \mathrm{~mm}$ NaSal on voltage-clamped cochlear spiral ganglion neurons at a holding potential of $-70 \mathrm{mV}$ had no effect $(n=7)$ (Fig. 4C,E). In contrast, $1 \mathrm{~mm}$ Glu elicited a current response of $89.53 \pm 14.55 \mathrm{pA}(n=$ 43) (Fig. 4C,E). When Glu was coapplied with $5 \mathrm{~mm} \mathrm{NaSal}$, the current increased by approximately sevenfold (673.32 \pm 90.54 pA; $n=43$ ) (Fig. 4C,E). Monitoring membrane potential under current clamp (Fig. $4 D, F)$ showed that the application of $\mathrm{Na}$ Sal alone did not produce any significant effect on the cell voltage $(n=5)$, whereas its coapplication with Glu induced a fourfold increase of the membrane voltage $(13.78 \pm 5.29 \mathrm{mV} ; n=7)$ relative to the application of Glu alone $(3.78 \pm 1.82 \mathrm{mV}$; $n=7$ ) (Fig. $4 D, F)$. The presence of $50 \mu \mathrm{M}$ NMDA antagonists MK-801 in the bath solution prevented the augmentation of Glu responses by NaSal $(31.42 \pm 24.27 \mathrm{pA}$; $n=7$ ) (Fig. 4C,E). We therefore conclude that the NaSal augmentation of Glu responses is mediated by the enabling of NMDA receptors that were not active before the application of NaSal. Consistently, current response to $1 \mathrm{mM}$ AMPA (88.57 \pm $5.84 \mathrm{pA} ; n=7)$ was unaffected by the presence of NaSal (90 $\pm 5.34 ; n=7$ ) (Fig. $5 A, D)$.

\section{Salicylate enables NMDA responses of cochlear spiral ganglion neurons}

NMDA receptors are present on the auditory nerve terminals, but application of 1 mM NMDA did not elicit any detectable current on voltage-clamped cochlear spiral ganglion neuron even when administered in $0 \mathrm{Mg}^{2+}$ with $10 \mu \mathrm{M}$ glycine (Fig. $5 B, D$ ). This observation is consistent with previous reports (Nakagawa et al., 1991; Ruel et al., 1999; Jagger et al., 2000; Glowatzki and Fuchs, 2002) that also failed to detect a response to NMDA, indicating that cochlear synaptic transmission is not carried by NMDA receptors but rather by rapidly gating AMPA receptors. Thus, both NMDA and NaSal when applied alone evoked no response. In contrast, coapplication of $\mathrm{Na}$ Sal (5 mM) with NMDA (1 mM) evoked a large inward current (1758.33 \pm 367.06 pA; $n=6$ ) (Fig. $5 B, D$ ). Thus, NaSal enabled the NMDA response.

Lack of action on the redox site of NMDA receptors

Because salicylate has been shown to act as a free radical scavenger (Sha et al., 2001), we tested the effect of the selective reducing agent dithiothreitol (DTT), which is known to potentiate NMDA-induced currents (Aizenman et al., 1989). In our hands, $1 \mathrm{~mm}$ DTT alone did not produce any current activation $(n=4)$, and its coapplication with Glu did not increase the Glu responses (data not shown), indicating that the augmenting effect of $\mathrm{NaSal}$ 

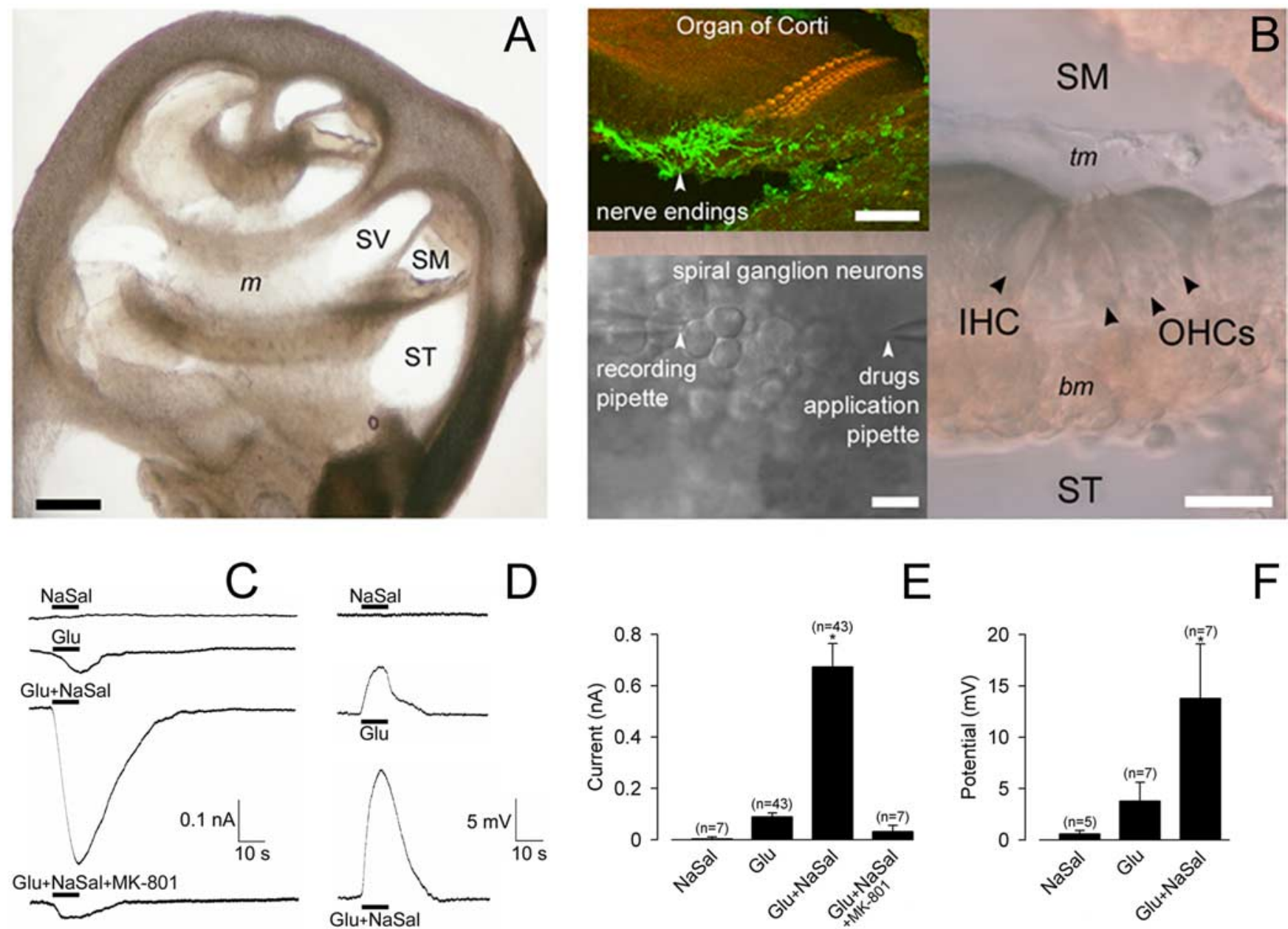

Figure 4. Sodium salicylate increases Glu response of cochlear spiral ganglion neurons. $A$, Voltage- and current-clamp measurements were performed on cochlear spiral ganglion neuron somata from cochlear slices of neonate rat (scale bar, $500 \mu \mathrm{m}$ ). m, Modiolus; SM, scala media; ST, scala tympani; SV, scala vestibule. $\boldsymbol{B}$, This preparation allows a clear view of the IHCs and OHCs and the cochlear spiral ganglion neurons. Scale bar, $20 \mu \mathrm{m}$. Top inset, Confocal immunolocalization of hair cells (red, rhodamine phalloidin) and nerve terminals (green, neurofilament). Scale bar, $150 \mu \mathrm{m}$. Bottom inset, Recording and drug delivery pipettes. Scale bar, $20 \mu \mathrm{m}$. bm, Basilar membrane; tm, tectorial membrane. C, $\boldsymbol{D}$, Shown are voltage- and current-clamp recordings from cochlear spiral ganglion neuron somata after application of $5 \mathrm{~mm}$ NaSal alone, $1 \mathrm{~mm}$ Glu alone, $1 \mathrm{~mm}$ Glu with $5 \mathrm{~mm}$ NaSal in the bath, and after Glu with NaSal plus $50 \mu \mathrm{m}$ MK-801. Although application of NaSal alone had no effect, it dramatically increases the Glu-induced currents and voltage response. Coapplication of $50 \mu \mathrm{M}$ MK-801 prevented augmentation of the Glu response. $\boldsymbol{E}, \boldsymbol{F}$, Quantification of currents and voltage variations. Each bar represents the amplitude of currents and membrane potentials. The number of cells is given above each bar. Data are expressed as mean \pm SEM. ${ }^{*} p<0.01$, statistically significant from Glu alone.

on the Glu responses was not attributable to an action on the redox site of NMDA receptors.

Salicylate activates arachidonic-acid-sensitive NMDA responses Salicylate has been shown to inhibit cyclooxygenase activity (Vane, 1971; Mitchell et al., 1993; Vane and Botting, 1998), leading to an increase of intracellular arachidonic acid (Thiemermann, 1991; Vane and Botting, 1998). We thus investigated whether salicylate-induced NMDA responses are linked to an increase of arachidonic acid by testing the effects of arachidonic acid on voltage-clamped spiral ganglion neuron somata in slices of neonate rat cochleae. Arachidonic acid $(10 \mu \mathrm{M})$ alone induced no response (data not shown), but the coapplication of arachidonic acid with NMDA induced a clear response $(200 \pm 54 \mathrm{pA}$; $n=6$ ) (Fig. $5 C, D$ ). Thus, like NaSal, the arachidonic acid enabled the NMDA response.

Salicylate acts at synaptic NMDA receptors

$\mathrm{NaSal}$ effects were evaluated by monitoring intracellular calcium change at the level of a single postsynaptic afferent bouton using two-photon fluorescence laser microscopy (Fig. 6A,B) (Boyer et al., 2004). Iontophoretic application of Glu at the basal pole of IHCs transiently increased the resting $\left[\mathrm{Ca}^{2+}\right]_{\mathrm{i}}$ (three of three cells, five boutons; $70.5 \pm 17 \% \Delta F / F_{0}$ ) (Fig. $6 C-E$ ). Application of $5 \mathrm{~mm} \mathrm{NaSal}$ in the bathing solution was ineffective in changing $\left[\mathrm{Ca}^{2+}\right]_{\mathrm{i}}$. The Glu-induced $\left[\mathrm{Ca}^{2+}\right]_{\mathrm{i}}$ increase was greater when the Glu was applied in the presence of $\mathrm{NaSal}(5 \mathrm{~mm})$ in the bathing solution (three of three cells, five boutons; $195 \pm 7.1 \% \Delta F / F_{0}$ ). The effect of NaSal was prevented by $50 \mu \mathrm{M} \mathrm{MK}-801$ added to the bath (Fig. 6C-E). Thus, it appears that NaSal enabled NMDA receptors to contribute to the response to Glu.

\section{Salicylate induces hearing loss and neural excitation in the auditory nerve}

Salicylate-induced hearing loss is not linked to NMDA receptors Patch-clamp and calcium imaging data were obtained on whole cochlear slices from neonatal rats (aged between P0 and P5). However, hearing in rats commences at approximately P10. We thus needed to verify that the results obtained on cochlear slices from immature cochleae could be extended to mature guinea pig cochlea (Fig. 7A). We first measured the CAP of the auditory 


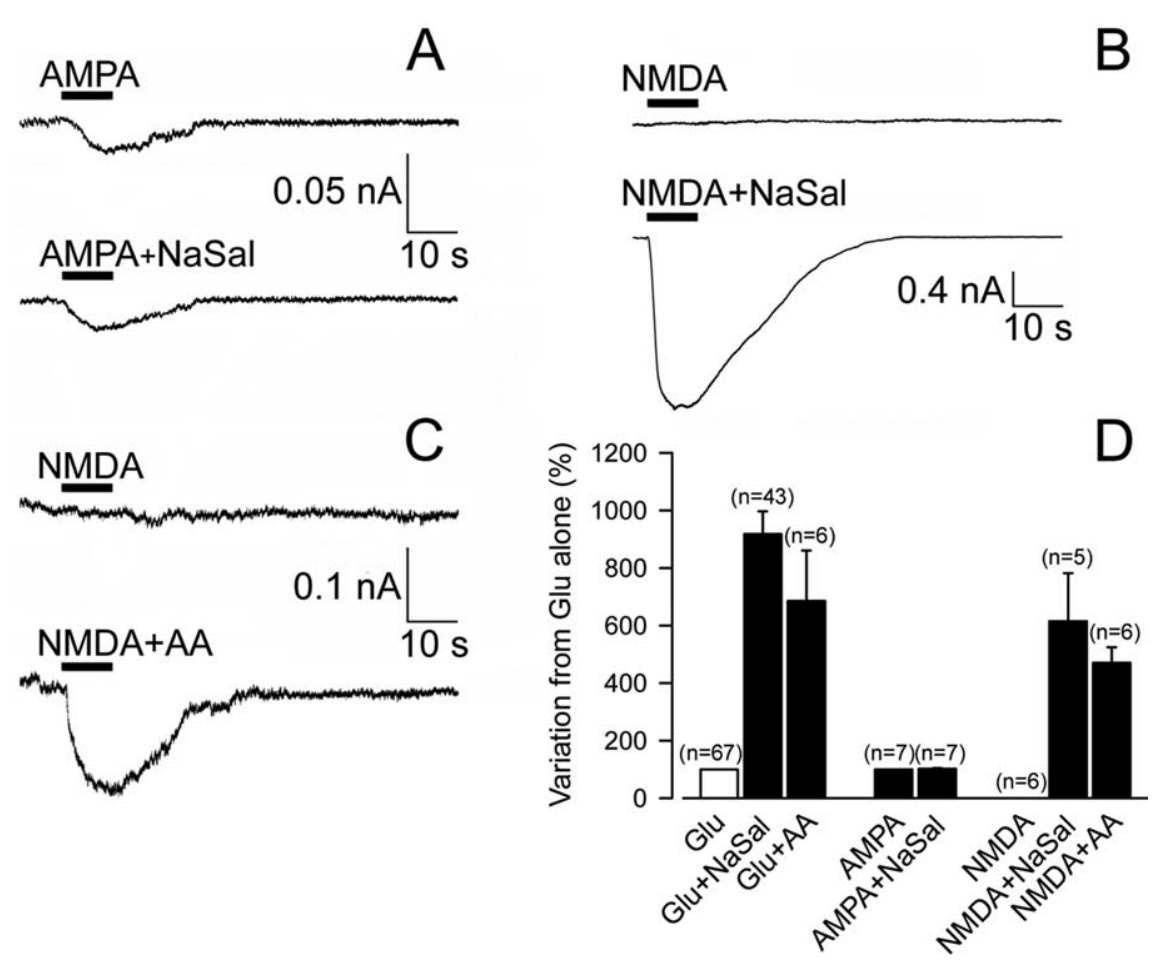

Figure 5. Sodium salicylate enables arachidonic-acid-sensitive NMDA responses of cochlear spiral ganglion neurons. $\boldsymbol{A}-\boldsymbol{C}$, Voltage-clamp measurements were performed on cochlear spiral ganglion neuron somata from cochlear slices of neonate rat. Current responses induced by $1 \mathrm{~mm}$ AMPA with $5 \mathrm{~mm}$ NaSal, $1 \mathrm{~mm}$ NMDA with $5 \mathrm{~mm} \mathrm{NaSal}$, and $1 \mathrm{~mm}$ NMDA with $10 \mu \mathrm{m}$ arachidonic acid (AA). D, Quantification of the current variations. Each bar represents the amplitude of currents expressed in percentage from the initial Glu responses. The number of cells is given above each bar. Data are expressed as mean \pm SEM.

effect on the spontaneous activity of auditory fibers, indicating that NMDA receptors were not actively contributing to the spontaneous activity. However, the NMDA antagonist reversed the NaSalinduced increase in spontaneous activity $(n=9)$ (Fig. $8 B, D)$. No significant difference in the spontaneous rate was seen between control artificial perilymph and $\mathrm{Na}$ Sal plus MK-801 perfusion ( $t$ test, $p=$ $0.1234 ; \mathrm{df}=8$ ). This indicates that the NaSal enabled NMDA receptors to contribute to the spontaneous activity. That AMPA receptors were not involved in the action of NaSal is indicated by the fact that the AMPA antagonist GYKI $53784(50 \mu \mathrm{M})$ silenced the fibers $(n=2)$, but NaSal was still able to evoke spike activity, to values even greater than those recorded during the initial pre-perfusion rate (Fig. $8 C$ ). NaSal induced no change in the firing rate of auditory nerve fibers with a spontaneous discharge rate below 0.5 spikes/s ( 2 of 17; data not shown). However, adding a moderate continuous white noise to increase the basal activity of these fibers did make these low-spontaneous-rate fibers reactive to NaSal.

To estimate the regularity of the spontaneous firing rate, we calculated a coefficient of variation (Fig. $8 A-C$ ). In the case of a Poisson distribution, the coefficient of

nerve and DPOAEs. The latter selectively reflects the OHC functioning. Whereas artificial perilymph alone had no effect, a 10 min perfusion of NaSal induced a CAP threshold elevation of $35 \pm 3.2 \mathrm{~dB}(n=5)$ and a disappearance of the DPOAEs into the noise floor $(n=5)$. These effects have been reported by others and are attributed to, and consistent with, an action of salicylate on the OHCs (Puel et al., 1989, 1990; Kujawa et al., 1992). The NMDA antagonist MK-801 did not reverse the effects of NaSal on CAP and DPOAEs (Fig. $7 B, C$ ). This confirms that the action of salicylate at the OHCs does not involve NMDA receptors.

Recording single auditory nerve fibers while performing perilymphatic perfusion is technically extremely difficult. However, we were successful in obtaining complete data (i.e., spontaneous activity and tuning curves before and after perilymph alone, after NaSal alone, and after NaSal plus MK-801) for two fibers. These recordings showed that NaSal elevates thresholds at the characteristic frequency (CF) of the fiber, leaving the low-frequency tail almost unaffected (Fig. 7D). These actions of salicylate have been reported by others (Stypulkowski, 1990) and are also consistent with an action of salicylate at the OHCs. No recovery of the CF threshold was obtained in the presence of MK-801 (Fig. 7D), further confirming that NaSal-induced hearing loss, or action at the OHCs, does not depend on NMDA receptors.

\section{Salicylate increase spontaneous discharge rate of auditory nerve fibers}

Perilymphatic perfusion of $\mathrm{NaSal}(5 \mathrm{~mm})$ induced an increase of spontaneous spike rate in auditory nerve fibers (Fig. $8 A, B$ ). The spontaneous discharge rate of single-unit auditory nerve fibers significantly increased from $17 \pm 5.1$ to $40 \pm 8.7$ spikes/s ( $t$ test, $p=0.013$; df $=16 ; n=17$; CF of between 6 and $26 \mathrm{kHz}$ ) (Fig. $8 D)$. The intracochlear perfusion of $50 \mu \mathrm{M} \mathrm{MK}-801$ alone had no variation is equal to 1 . A value $>1$ reveals a broad interspike distribution. Except for the fluctuations attributable to the low spontaneous rate of the fiber (Fig. $8 \mathrm{~A}$ ), the coefficient of variation remained stable around 1 in all the experimental conditions (Fig. $8 B, C, E)$, indicating that NaSal simply increased the spiking rate without any bursting.

\section{Salicylate increases arachidonic acid content in the cochlea in vivo}

Based on our patch-clamp recordings of cochlear spiral ganglion neurons showing NaSal-like enabling of NMDA responses with arachidonic acid, we measured free arachidonic acid content in cochleae perfused with artificial perilymph alone $(n=3$; control) or containing $5 \mathrm{~mm} \mathrm{NaSal}(n=3)$ for $10 \mathrm{~min}$ in vivo. Gas liquid chromatography data showed that free arachidonic acid increased by $40 \%$ in the NaSal-perfused cochleae compared with the perilymph-perfused controls (Fig. $8 F$ ). These results are consistent with those of Jung et al. (1992) who reported that application of $\mathrm{NaSal}$ onto the round window membrane of the adult chinchilla cochlea induces a dose-dependent elevation of auditory brainstem thresholds associated with alterations in levels of arachidonic acid metabolites (eicosanoids) in the perilymph content. Concomitantly, $\mathrm{NaSal}$ induced a slight increase of free oleate (4\%) and a decrease of palmitate and stearate of $\sim 15$ and $18 \%$, respectively (Fig. $8 \mathrm{~F}$ ). Thus, it appears that the NaSal increase in arachidonate levels caused the enabling of the NMDA receptor responses observed.

\section{Discussion}

The present study reports for the first time the presence of NMDA receptors at IHC synapses. Patch-clamp recordings and 

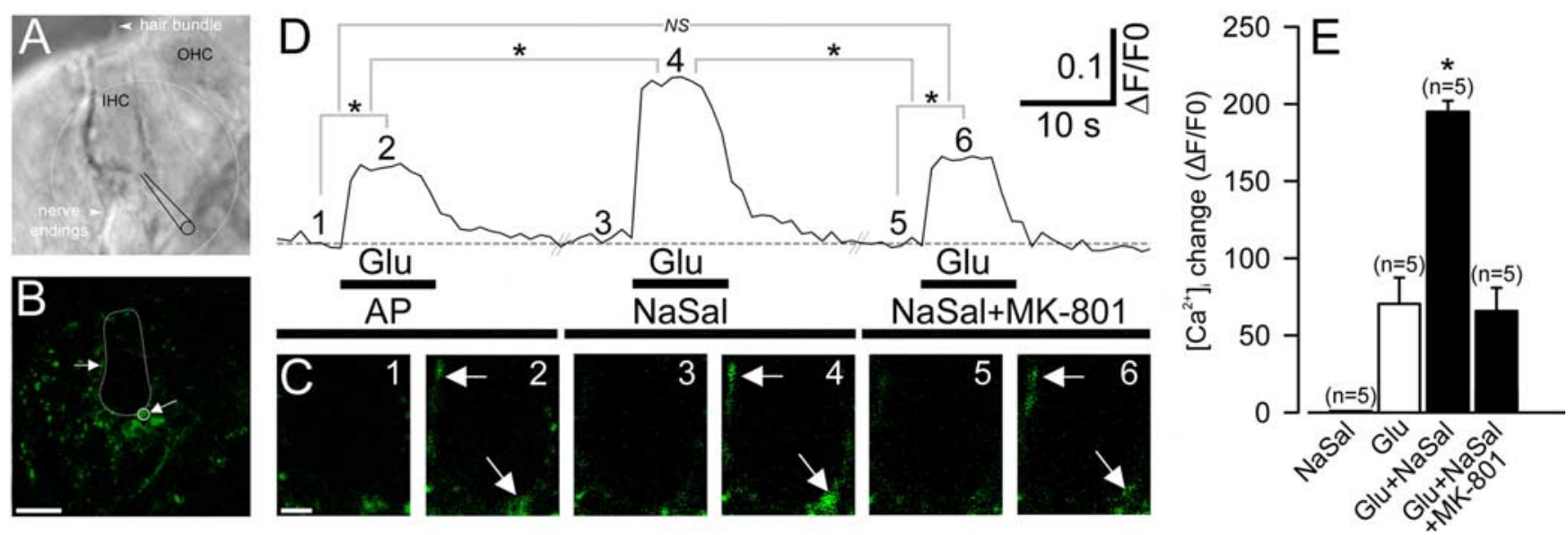

Figure 6. Sodium salicylate enables Glu-induced calcium influxes through NMDA receptors located on the nerve endings of cochlear spiral ganglion neurons. $A, 0$ ptical section of an IHC from neonatal rat cochlear slice. Note the hair bundle and the auditory nerve terminals apposed against the basolateral membrane of the IHC. The tip of the pipette for iontophoretic application of $10 \mathrm{~mm}$ Glu appears on the right side of the basal pole of the IHC. Preliminary experiments with Lucifer yellow showed that the dye fluorescence spreads in a circular pattern up to $50 \mu \mathrm{m}$ radially from the pipette tip. $\boldsymbol{B}$, Two-photon imaging from the same section as shown in $\boldsymbol{A}$. Afferent boutons appear as bright spots surrounding the IHCs (arrows) apposed against the basolateral membrane of the IHC. C, Higher magnification taken at different times. Shown are fluorescence changes (arrows) before (1) and after (2) iontophoretic application of Glu at the basal pole of the IHC, as shown in $\boldsymbol{A}$. Iontophoretic applications of Glu were then repeated with $5 \mathrm{~mm} \mathrm{NaSal}(3,4)$ and with NaSal plus $50 \mu \mathrm{m} \mathrm{MK-801}(5,6)$ in the bathing solution. $\boldsymbol{D}$, Line profile of the fluorescence changes in the bright spot circled in $\boldsymbol{B}$. Each bath application was separated by $60 \mathrm{~s}$. $\boldsymbol{E}$, Quantification of the fluorescence changes in afferent boutons. Each bar represents fluorescence change expressed in percentage from the initial Glu responses. The number of boutons is given above each bar. Data are expressed as mean \pm SEM. ${ }^{*} p<0.01$. Scale bars: (in $\left.B\right) A, B, 10 \mu \mathrm{m} ; C, 2.5 \mu \mathrm{m}$.

two-photon calcium imaging on whole cochlear slices from postnatal rat shows that NaSal enabled an NMDA response that was otherwise absent. This NaSal-enabled NMDA response could be mimicked by the application of arachidonic acid and was blocked by MK-801. NaSal increased the levels of arachidonic acid in the whole cochlea in vivo. Single-unit recordings from adult guinea pigs confirmed the NaSalenabled NMDA neuronal excitatory responses. In addition, NaSal increased arachidonic acid levels in the cochlea.

\section{NMDA receptors are located on the IHC synapse}

Previous data indicates that spiral ganglion somata would express NMDA receptor subunits (NR1 and NR2A-NR2AD) (Safieddine and Eybalin, 1992; Kuriyama et al., 1993; Niedzielski and Wenthold, 1995; Puel et al., 1995; Usami et al., 1995). Our Western blots confirm the expression of NR1, NR2B, and NR2D in the cochlea. They are also in line with a possible expression of NR2C but not with that of NR2A. Interestingly, the fact that NR2A could not be detected in the cochlea suggests that the anti-NR2A/B antibody we used for the immunoelectron microscopy only recognized NR2B.

The expression of NMDA receptors at adult IHC synapses has remained controversial because of difficulties in recording their activity (Puel, 1995). Our present confocal and ultrastructural results revealing the presence of NR1 and NR2B at the postsynaptic density of IHC synapses sug-
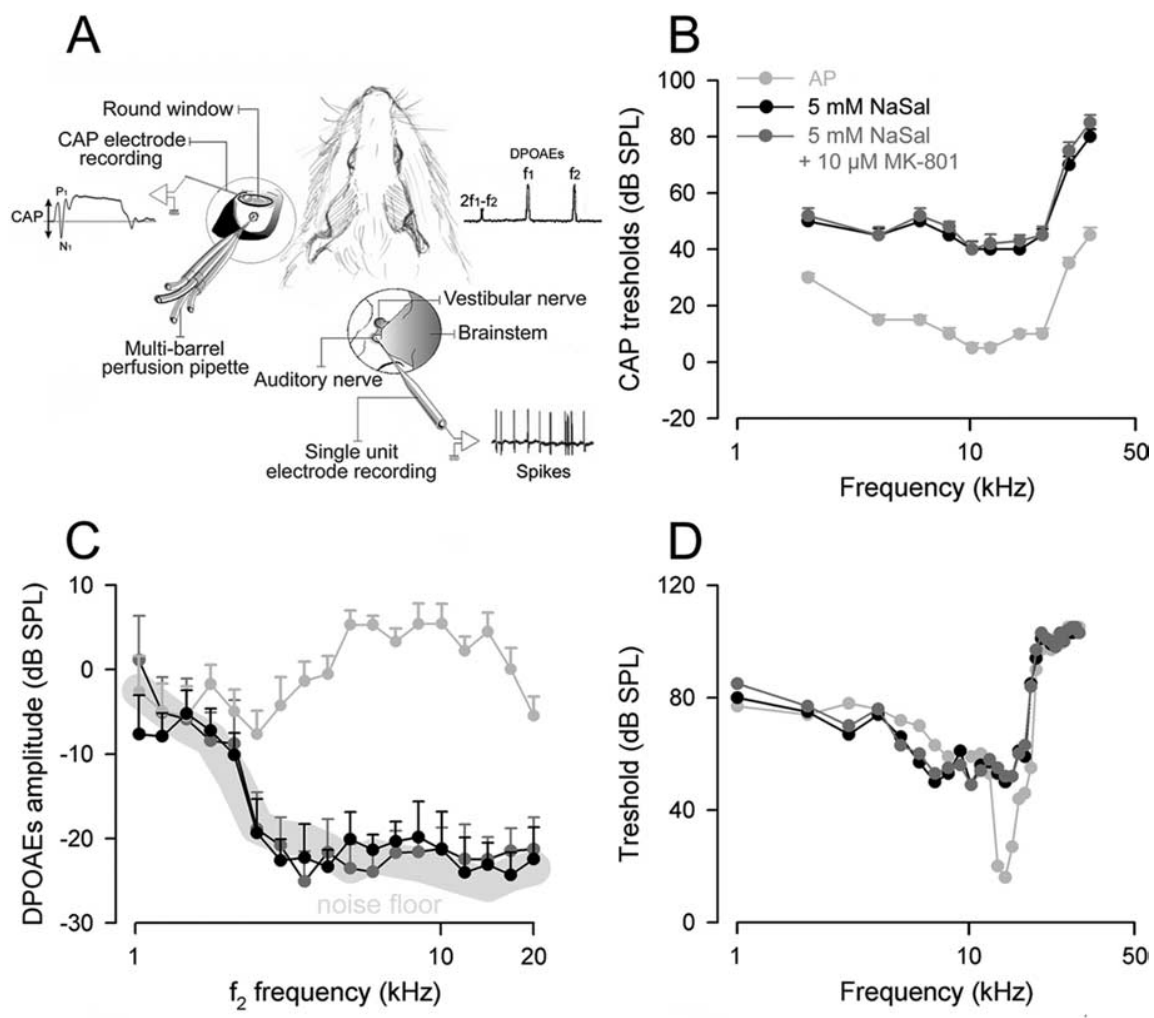

Figure 7. Effect of sodium salicylate on compound action potential and single-unit tuning curves from the auditory nerve and distortion product otoacoustic emissions. $A$, Shown are the physiological parameters monitored during perilymphatic perfusion of artificial perilymph alone or containing $5 \mathrm{~mm} \mathrm{NaSal}$. After a dorsal approach, one hole was drilled in the scala tympani to receive the multibarrel drug delivery pipette. A second hole drilled at the apex allowed the perfused solution to flow out of the cochlea. A silver electrode was placed onto the round window membrane to record the CAP $\left(\mathrm{N}_{1}-\mathrm{P}_{1}\right)$ of the auditory nerve. DPOAEs were recorded from a probe placed in the external auditory meatus. The auditory nerve was exposed through a posterior fossa approach to record single-unit action potentials (spikes) using a microelectrode. B, C, CAP and DPOAE audiograms were recorded after 10 min perfusion of control artificial perilymph (AP; gray circle), 10 min perfusion of control artificial perilymph containing $5 \mathrm{~mm}$ $\mathrm{NaSal}$ (black circle), and $10 \mathrm{~min}$ perfusion of $5 \mathrm{~mm}$ NaSal plus $50 \mu \mathrm{m}$ MK-801 (dark gray circle). D, A tuning curve from a single-unit fiber coding for $14 \mathrm{kHz}$. 

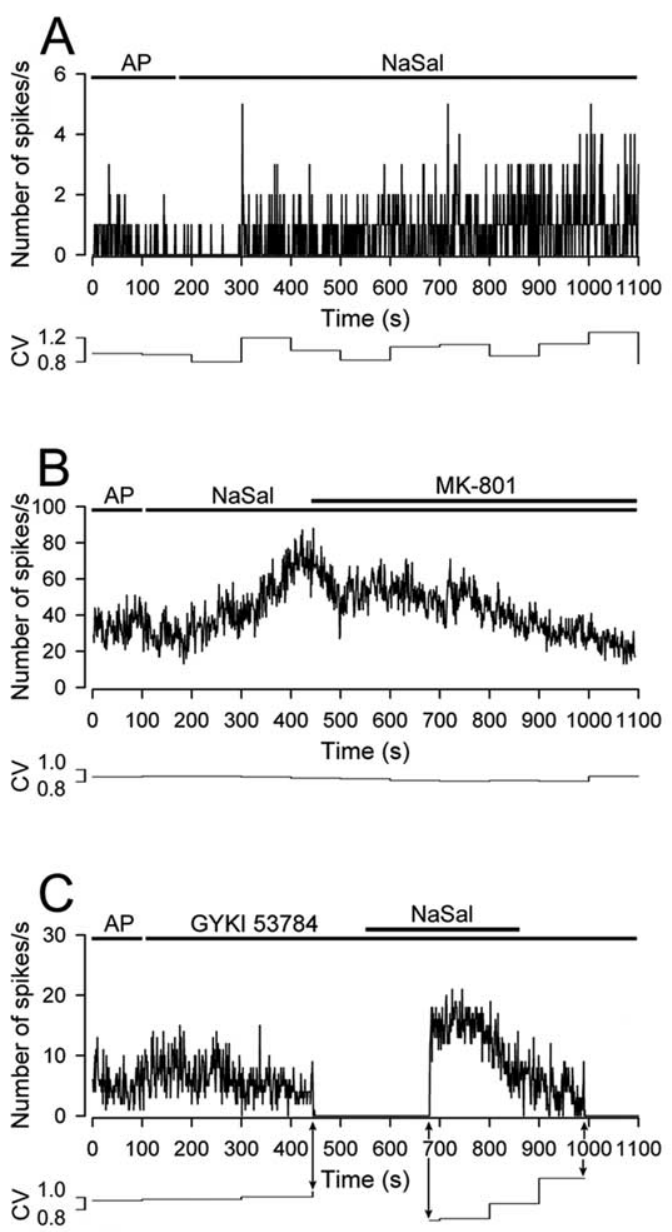

with no participation of NMDA receptors. Conversely, behavioral studies showed that tinnitus induced by cyclooxygenase blockers (salicylate, mefenamate) were mediated by cochlear NMDA receptors (Guitton et al., 2003). We thus raised the hypothesis that salicylate modulates the IHC synaptic neurotransmission via NMDA receptors.

Whole-cell voltage-clamp measurements from cochlear slices showed that application of $\mathrm{NaSal}$ alone elicited no inward current or membrane depolarization in spiral ganglion neurons, which responded positively to Glu. Glu-induced peak current amplitude and membrane depolarization were considerably increased in the presence of NaSal by enabling NMDA receptor activation. Consistently, Peng et al. (2003) reported an aspirin-induced potentiation of NMDA responses on cultured spiral ganglion neurons from young postnatal mice. The main difference between our respective results is that Peng et al. (2003) also reported NMDA-mediated responses without aspirin. Because functional NMDA receptors are not identified in freshly dissociated spiral ganglion neurons (Nakagawa et al., 1991; Ruel et al., 1999), their presence in the Peng et al. (2003) experiments could be attributable to cell culture procedures that changed NMDA receptor expression.

Mechanisms by which salicylate enables cochlear NMDA response

Extracellular $p H$ is not involved in NMDA receptor modulation

Acidification inhibits and alkaline $\mathrm{pH}$ potentiates NMDA responses (Low et al., 2000). Thus, salicylate effects may be attributable to extracellular $\mathrm{pH}$ alteration. However, in our experiments, salicylate solutions were buffered to keep a neutral $\mathrm{pH}$, and salicylate alone induced no currentand voltage-clamp responses. In addition, reducing agents such as DTT potentiate NMDA responses via redox site modulation (Aizenman et al., 1989, 1990). In our study, DTT had no effect on Glu-induced

gest that they would indeed exist at this ribbon synapse. Our finding of faint presynaptic NR1 and NR2A/B immunoreactivities in the IHC membrane beneath the synaptic ribbons further suggests that the NMDA receptor subunit expression in these cells, described as transient in postnatally maturing cochleae by Knipper et al. (1997), was in fact downregulated but still present in adulthood.

\section{Salicylate modulates NMDA receptor responses}

The application of NMDA elicited no detectable current on spiral ganglion somata or calcium change in postsynaptic afferent boutons. These results are consistent with others (Nakagawa et al., 1991; Ruel et al., 1999; Glowatzki and Fuchs, 2002) reporting that cochlear synaptic transmission is carried by AMPA receptors responses, indicating that the NaSal-induced increase of Glu responses was not attributable to an action on the redox site of NMDA receptors.

Enabling NMDA receptors is linked to arachidonic acid When Glu was coapplied with arachidonic acid, the responses it induced were increased and NMDA responses clearly enabled, in agreement with Casado and Ascher (1998) who reported potentiations by arachidonic acid in native and recombinant NMDA receptors.

Our gas liquid chromatography measurements showed that free arachidonic acid increased by $40 \%$ in the NaSal-perfused cochleae compared with perilymph-perfused controls. In the 
meantime, NaSal induced a slight increase of free oleate (4\%) and a $\sim 15$ and $18 \%$ decrease of palmitate and stearate cochlear content, respectively. Arachidonate is mainly generated from phospholipids via phospholipase A2 activity (Corda et al., 2002), with the remainder of lysophospholipids triggering many biological activities (Chun and Rosen, 2006; Meyer zu Heringdorf and Jakobs, 2007). Because lysophospholipids are noxious to cellular functioning (Farooqui et al., 1997; Farooqui and Horrocks, 2006), it may be expected that the decrease in cellular saturated free fatty acids such as palmitate and stearate is attributable to a rapid two-acylation of excess lysophosphospholipids via lysophospholipid/acyltransferase activity to eliminate lysophospholipids and to restore phospholipids levels (Purdon and Rapoport, 1998; Chun and Rosen, 2006). This "homeostatic" regulation of free fatty acids is supported by the opposite modulation of NMDA receptor responses by lysophospholipids and arachidonic acid in cultured mice neurons (Casado and Ascher, 1998).

\section{Site of action of salicylate}

NaSal effects were evaluated by monitoring intracellular calcium changes at the level of single postsynaptic afferent boutons. Although NMDA alone had no effect, NaSal induced a clear increase of Glu-induced calcium responses that could be blocked by MK- 801 . These observations suggest that the same mechanisms of $\mathrm{NaSal}$ action occurred in the spiral ganglion somata and at IHC synapses.

Functional OHCs are required for normal CAP and/or singleunit thresholds. DPOAEs reflect normal OHC functioning, which is the anatomical support of the active mechanisms responsible for the exquisite cochlear sensibility and frequency selectivity. Consequently, the CAP and single-unit threshold increases in presence of $\mathrm{NaSal}$, together with the abolition of DPOAEs, attests that the hearing loss is attributable to an effect of NaSal on OHCs. Because MK-801 could not reverse these effects, we conclude that NaSal-induced hearing loss does not involve NMDA receptors.

It is known that the loss of active mechanisms decreases the auditory nerve fiber spontaneous activity (Wiederhold and Kiang, 1970). In contrast, salicylate increased, and not decreased, the spontaneous activity. It is worth noting the large increase of Glu currents on spiral ganglion neurons induced by salicylate in neonate cochlea. Although we cannot exclude different NMDA receptors functioning in mature and immature cochleae, one may assume that, in the adult cochlea, the NaSal-induced increase of auditory nerve activity counterbalances the decrease attributable to the loss of active mechanisms. Interestingly, NaSal induced no change in the auditory nerve fiber firing rate with a spontaneous discharge rate $<0.5$ spikes/s. However, adding a moderate white noise to increase the basal activity of these fibers did make these low-spontaneous-rate fibers reactive to NaSal. These results indicate that the Glu presence in the IHC synaptic cleft is essential to salicylate-induced neural excitation and that the later is attributable to the enabling action of NaSal on NMDA receptors.

Although our ultrastructural immunocytochemical data suggest that NMDA receptors are mainly located on the afferent dendritic terminals contacting the IHCs, the faint labeling at the base of the synatic ribbons does not exclude that salicylate may also act at the presynaptic IHC level. Consequently, the increase of the spontaneous spiking rate observed during perilymphatic perfusion of salicylate in vivo may partially be attributable to an activation of NMDA autoreceptors on the IHCs, which in turn would increase Glu release, as described previously in the CNS
(Berretta and Jones, 1996; Breukel et al., 1998; Woodhall et al., 2001; Yang et al., 2006; Luccini et al., 2007). However, the excitatory effect of NaSal in the presence of GYKI 53784, which completely inhibits AMPA receptors (Ruel et al., 2000), argues against an activation of IHC NMDA autoreceptors as a unique mechanism of NaSal action. Consequently, although an implication of NMDA autoreceptors cannot totally be excluded, it is more likely that NaSal mainly enables NMDA responses from postsynaptic receptors at the IHC synapse. Only direct patch recordings from single terminal boutons of these dendrites would clarify the mechanisms of the NaSal-induced neural excitation (i.e., summation of NMDA-mediated EPSPs alone or combination with AMPA receptor-mediated EPSPs).

In conclusion, we provide direct evidence for a new pharmacological profile of NaSal. NaSal induced an increase in arachidonic acid levels that in turn enabled NMDA receptors at the IHC basal poles to be activated by Glu. Although the implication of cochlear NMDA receptors in pathological conditions is long known (Puel, 1995), their role in the intact nonpathological cochlea remains elusive. Chen et al. (2007) reported that NMDA receptors modulate synaptic efficiency by regulating the number of surface AMPA receptors of spiral ganglion neurons. Extending our previous studies demonstrating that the NaSal-induced tinnitus was blocked by application of NMDA antagonists into the cochlear fluids (Guitton et al., 2003), our present work provides a new molecular mechanism accounting for the generation of tinnitus at the periphery of the auditory system.

\section{References}

Aizenman E, Lipton SA, Loring RH (1989) Selective modulation of NMDA responses by reduction and oxidation. Neuron 2:1257-1263.

Aizenman E, Hartnett KA, Reynolds IJ (1990) Oxygen free radicals regulate NMDA receptor function via a redox modulatory site. Neuron 5:841-846.

Berretta N, Jones RSG (1996) Tonic facilitation of glutamate release by presynaptic $N$-methyl-D-aspartate autoreceptors in the entorhinal cortex. Neuroscience 75:339-344.

Bourien J, Ruel J, Senhadji L, Puel JL (2007) Comparison of three spike detectors dedicated to single unit action potentials of the auditory nerve. Conf Proc IEEE Eng Med Biol Soc 1:1430-1433.

Boyer S, Ruel J, Puel JL, Chabbert C (2004) A procedure to label inner ear afferent nerve endings for calcium imaging. Brain Res Protoc 13:91-98.

Breukel AI, Besselsen E, Lopes da Silva FH, Ghijsen WE (1998) A presynaptic $N$-methyl-D-aspartate autoreceptor in rat hippocampus modulating amino acid release from a cytoplasmic pool. Eur J Neurosci 10:106-114.

Casado M, Ascher P (1998) Opposite modulation of NMDA receptors by lysophospholipids and arachidonic acid: common features with mechanosensitivity. J Physiol 513:317-330.

Cazals Y, Horner KC, Huang ZW (1998) Alterations in average spectrum of cochleoneural activity by long-term salicylate treatment in the guinea pig: a plausible index of tinnitus. J Neurophysiol 80:2113-2120.

Chen Z, Kujawa SG, Sewell WF (2007) Auditory sensitivity regulation via rapid changes in expression of surface AMPA receptors. Nat Neurosci 10:1238-1240.

Chun J, Rosen H (2006) Lysophospholipid receptors as potential drug targets in tissue transplantation and autoimmune diseases. Curr Pharm Des $12: 161-171$.

Corda D, Iurisci C, Berrie CP (2002) Biological activities and metabolism of the lysophosphoinositides and glycerophosphoinositols. Biochim Biophys Acta 1582:52-69.

Evans EF, Borerwe TA (1982) Ototoxic effects of salicylates on the responses of single cochlear nerve fibres and on cochlear potentials. Br J Audiol 16:101-108.

Evans EF, Wilson JP, Borerwe TA (1981) Animal models of tinnitus. CIBA Found Symp 85:108-138.

Eybalin M, Ripoll C (1990) Immunolocalization of parvalbumin in two glutamatergic cell types of the guinea pig cochlea: inner hair cells and spinal ganglion neurons (in French). C R Acad Sci III 310:639-644. 
Farooqui AA, Horrocks LA (2006) Phospholipase A2-generated lipid mediators in the brain: the good, the bad, and the ugly. Neuroscientist 12:245-260.

Farooqui AA, Yang HC, Rosenberger TA, Horrocks LA (1997) Phospholipase A2 and its role in brain tissue. J Neurochem 69:889-901.

Folch J, Lees M, Sloane Stanley GH (1957) A simple method for the isolation and purification of total lipides from animal tissues. J Biol Chem 226:497-509.

Glowatzki E, Fuchs PA (2002) Transmitter release at the hair cell ribbon synapse. Nat Neurosci 5:147-154.

Guitton MJ, Caston J, Ruel J, Johnson RM, Pujol R, Puel JL (2003) Salicylate induces tinnitus through activation of cochlear NMDA receptors. J Neurosci 23:3944-3952.

Jagger DJ, Robertson D, Housley GD (2000) A technique for slicing the rat cochlea around the onset of hearing. J Neurosci Methods 104:77-86.

Jung TT, Park YM, Miller SK, Rozehnal S, Woo HY, Baer W (1992) Effect of exogenous arachidonic acid metabolites applied on round window membrane on hearing and their levels in the perilymph. Acta Otolaryngol Suppl 493:171-176.

Kakehata S, Santos-Sacchi J (1996) Effects of salicylate and lanthanides on outer hair cell motility and associated gating charge. J Neurosci 16:4881-4889.

Knipper M, Köpschall I, Rohbock K, Köpke AK, Bonk I, Zimmermann U, Zenner H (1997) Transient expression of NMDA receptors during rearrangement of AMPA-receptor-expressing fibers in the developing inner ear. Cell Tissue Res 287:23-41.

Kujawa SG, Fallon M, Bobbin RP (1992) Intracochlear salicylate reduces low-intensity acoustic and cochlear microphonic distortion products. Hear Res 64:73-80.

Kuriyama H, Albin RL, Altschuler RA (1993) Expression of NMDAreceptor mRNA in the rat cochlea. Hear Res 69:215-220.

Low CM, Zheng F, Lyuboslavsky P, Traynelis SF (2000) Molecular determinants of coordinated proton and zinc inhibition of $N$-methyl-D-aspartate NR1/NR2A receptors. Proc Natl Acad Sci U S A 97:11062-11067.

Luccini E, Musante V, Neri E, Raiteri M, Pittaluga A (2007) N-Methyl-Daspartate autoreceptors respond to low and high agonist concentrations by facilitating, respectively, exocytosis and carrier-mediated release of glutamate in rat hippocampus. J Neurosci Res 85:3657-3665.

Martin WH, Schwegler JW, Scheibelhoffer J, Ronis ML (1993) Salicylateinduced changes in cat auditory nerve activity. Laryngoscope 103:600-604.

McMahon CM, Patuzzi RB (2002) The origin of the $900 \mathrm{~Hz}$ spectral peak in spontaneous and sound-evoked round-window electrical activity. Hear Res 173:134-152.

Meyer zu HeringdorfD, Jakobs KH (2007) Lysophospholipid receptors: signalling, pharmacology and regulation by lysophospholipid metabolism. Biochim Biophys Acta 1768:923-940.

Mitchell JA, Akarasereenont P, Thiemermann C, Flower RJ, Vane JR (1993) Selectivity of nonsteroidal antiinflammatory drugs as inhibitors of constitutive and inducible cyclooxygenase. Proc Natl Acad Sci U S A 90:11693-11697.

Nakagawa T, Komune S, Uemura T, Akaike N (1991) Excitatory amino acid response in isolated spiral ganglion cells of guinea pig cochlea. J Neurophysiol 65:715-723.

Niedzielski AS, Wenthold RJ (1995) Expression of AMPA, kainate, and NMDA receptor subunits in cochlear and vestibular ganglia. J Neurosci 15:2338-2353.

Oliver D, He DZ, Klocker N, Ludwig J, Schulte U, Waldegger S, Ruppersberg
JP, Dallos P, Fakler B (2001) Intracellular anions as the voltage sensor of prestin, the outer hair cell motor protein. Science 292:2340-2343.

Peng BG, Chen S, Lin X (2003) Aspirin selectively augmented N-methyl-Daspartate types of glutamate responses in cultured spiral ganglion neurons of mice. Neurosci Lett 343:21-24.

Puel JL (1995) Chemical synaptic transmission in the cochlea. Prog Neurobiol 47:449-476.

Puel JL, Bledsoe Jr SC, Bobbin RP, Ceasar G, Fallon M (1989) Comparative actions of salicylate on the amphibian lateral line and guinea pig cochlea. Comp Biochem Physiol C 93:73-80.

Puel JL, Bobbin RP, Fallon M (1990) Salicylate, mefenamate, meclofenamate, and quinine on cochlear potentials. Otolaryngol Head Neck Surg 102:66-73.

Puel JL, Safieddine S, Gervais d'Aldin C, Eybalin M, Pujol R (1995) Synaptic regeneration and functional recovery after excitotoxic injury in the guinea pig cochlea. C R Acad Sci III 318:67-75.

Purdon AD, Rapoport SI (1998) Energy requirements for two aspects of phospholipid metabolism in mammalian brain. Biochem J 335:313-318.

Rouser G, Kritchevski G, Yamamoto A (1967) Lipid chromatographic analysis. New York: Dekker.

Ruel J, Chen C, Pujol R, Bobbin RP, Puel JL (1999) AMPA-preferring glutamate receptors in cochlear physiology of adult guinea-pig. J Physiol 518:667-680.

Ruel J, Bobbin RP, Vidal D, Pujol R, Puel JL (2000) The selective AMPA receptor antagonist GYKI 53784 blocks action potential generation and excitotoxicity in the guinea pig cochlea. Neuropharmacology 39:1959-1973.

Safieddine S, Eybalin M (1992) Co-expression of NMDA and AMPA/kainate receptor mRNAs in cochlear neurones. Neuroreport 3:1145-1148.

Schreiner CE, Snyder RL (1987) A physiological animal model of peripheral tinnitus In: Proceedings of the Third International Tinnitus Seminar (Feldmann H, ed), pp 100-106. Karlsruhe, Germany: Verlag.

Sha SH, Taylor R, Forge A, Schacht J (2001) Differential vulnerability of basal and apical hair cells is based on intrinsic susceptibility to free radicals. Hear Res 155:1-8.

Stypulkowski PH (1990) Mechanisms of salicylate ototoxicity. Hear Res 46:113-145.

Thiemermann C (1991) Biosynthesis and interaction of endotheliumderived vasoactive mediators. Eicosanoids 4:187-202.

Usami S, Matsubara A, Fujita S, Shinkawa H, Hayashi M (1995) NMDA (NMDAR1) and AMPA-type (GluR2/3) receptor subunits are expressed in the inner ear. Neuroreport 6:1161-1164.

Vane JR (1971) Inhibition of prostaglandin synthesis as a mechanism of action for aspirin-like drugs. Nat New Biol 231:232-235.

Vane JR, Botting RM (1998) Mechanism of action of antiinflammatory drugs. Int J Tissue React 20:3-15.

Wiederhold ML, Kiang NY (1970) Effects of electric stimulation of the crossed olivocochlear bundle on single auditory-nerve fibers in the cat. J Acoust Soc Am 48:950-965.

Woodhall G, Evans DI, Cunningham MO, Jones RS (2001) NR2Bcontaining NMDA autoreceptors at synapses on entorhinal cortical neurons. J Neurophysiol 86:1644-1651.

Yang J, Woodhall GL, Jones RS (2006) Tonic facilitation of glutamate release by presynaptic NR2B-containing NMDA receptors is increased in the entorhinal cortex of chronically epileptic rats. J Neurosci 26:406-410.

Zhang PC, Keleshian AM, Sachs F (2001) Voltage-induced membrane movement. Nature 413:428-432.

Zheng J, Shen W, He DZ, Long KB, Madison LD, Dallos P (2000) Prestin is the motor protein of cochlear outer hair cells. Nature 405:149-155. 